\title{
THE ROLE OF NON-ALLELIC INTERACTION IN INHERITANCE OF SOME ECONOMIC TRAITS IN G. BARBADENSE
}

\author{
Y. I. M. AL-Hibbiny, A. H. Mabrouk and Reham H. A. O. Gibely \\ Cotton Research Institute, Agricultural Research Center, Giza, Egypt
}

Received: Nov. 11, 2020

Accepted: Nov. 25,2020

\begin{abstract}
The triple test cross analysis was used to study different components of genetic variation by using 75 triple test cross families and their parents, $F_{1}$ and $F_{2}$ in one cotton cross (Giza $95 \times$ Australy) for yield, its components and fiber quality traits. The 75 TTC families $\left(25 \mathrm{~L}_{1}, 25 \mathrm{~L}_{2}\right.$ and $\left.25 \mathrm{~L}_{3}\right)$ were sown at Sakha Experimental Station; Agriculture Research Center, Kafr El-Sheikh government; Egypt. Mean squares between $L_{1}, L_{2}$ and $L_{3}$ were highly significant for all traits studied, while between $L_{1}$ and $L_{2}$ Families found to be significant for boll weight, lint percentage, lint index, fiber length and micronaire reading. Overall epistatic gene effects were highly significant differences for all traits studied except for fiber length and fiber strength. The (i) fixable type (additive $\times$ additive) was the most important epistatic effect than $\mathrm{j}$ and 1 non-fixable type for all traits. Both additive and dominance components were highly significant for all the traits studied. The degree of dominance was less than unity and confirmed the presence of partial dominance for all traits studied except for lint yield/plant; lint index and seed index were overdominance. The Additive gene action played an important role in controlling inheritance for all traits studied than dominance one except for lint yield/plant; lint index and seed index. Direction of dominance $(r)$ was non-significant for most traits indicating absence of dominance directional. Due to influence of (i) type of epistatic effects for the majority of the studied traits selection in early generations may be recommended. Genotypic correlation was positive and significant between yield traits and its components. This could help cotton breeder to use indirect selection to increase yield traits. All the studied traits showed higher proportion of recombinants inbreds falling outside parental range nearly $40 \%$. So, these higher values of prediction revealed that it would be feasible to predict as early as possible for transgressive segregation which can surpass parental range for most studied traits.
\end{abstract}

Key words: Cotton, Triple test cross, Epistasis, Additive, Dominance, Genotypic correlation.

\section{INTRODUCTION}

Large number of cultivars was developed from closely related parents indicating the presence of sufficient variability or mechanisms to create variability to achieve breeding progress in a narrow germplasm base. Unless improved methods to transfer useful allelic variations from diverse to adapted germplasm, cotton germplasm resources will remain limited. Breeders rely on genetic variation between parents to create unique genetic combination necessary for new superior cultivars. So, the understanding of the genetic architecture of each breeding materials is matter of a great interest for selecting the most desirable parents and crosses in order to establish the most efficient breeding program for quick and maximum genetic improvement

Triple test cross is one of the best design for detecting and estimating genetic components of variation for quantitative traits. It provides reliable information about the presence or 
absence of epistasis. Self-pollinated species like cotton, epistasis is perhaps more important to breeder than dominance, because the later is necessarily ephemeral in such species. The epistasis effects can be ignored and genetic models must be account for the estimation of inter-allelic interaction. Breeders need easier and reliable technique to obtain unbiased estimates of genetic components. Thus, $F_{2}$ triple test cross could used to be detected epistasis and gives unambiguous of additive and dominance components.

This knowledge could help breeder to decide the best breeding procedures to be followed for crop improvement. This model tests the presence of epistasis (additive $\times$ additive, additive $\times$ dominance, dominance $x$ dominance interactions) before deciding any breeding program. Also, estimate both genetic components; additive and dominance components if epistasis is absent (Sharma 1988 and Singh and Narayanan, 2013). So many cotton breeders have been used TTC analysis in cotton El-Mansy, 2005, Soliman et al., 2008; El-Lawendey et al., 2010; Saleh 2013; Dawwam, et al., 2016, Mahros, 2016 and EI-Mansy et al., 2020.

The present study aims to detect epistasis along with estimation of additive and dominance genetic components for yield and fiber quality traits in Egyptian cotton cross (Giza $95 \mathrm{x}$ Australy) through $75 F_{2}$ TTC families. The information obtained through present study would help in understanding the genetic basis of these studied traits and making breeding strategy for the development of high yielding or valuable germplasm in cotton. Also, the study computes the genotypic correlation among various traits and partitioning it to epistasis, additive and dominance correlations.

\section{MATERIALS AND METHODS}

This investigation was carried out at the Sakha Experimental Station; Agriculture Research Center, Kafr EISheikh government; Egypt, during four successive seasons 2016, 2017, 2018 and 2019. The material for this study comprised of an $F_{2}$ population from a cross between two parents of cotton namely Giza 95 and Australy belonging to Gossypium barbadense $L$. Twenty five plants were randomly selected from $F_{2}$ population used as males and backcrossed to three testers $P_{1}, P_{2}$ and $F_{1}$ to generate $25 L_{1 i}\left(P_{1} \times F_{2}\right), 25 L_{2 i}\left(P_{2} \times F_{2}\right)$ and $25 L_{3 i}\left(F_{1} \times F_{2}\right)$ families as suggested by Kearsey and Jinks 1968 during the growing season of 2018. Then 75 families (crosses) were planted in a completely randomized block design with three replications in the growing season of 2019. Each replicate consists of three rows for each family. The row was $7 \mathrm{~m}$ long, with $70 \mathrm{~cm}$ between rows and $40 \mathrm{~cm}$ between plants within rows. Hills were thinned to keep a constant stand of one plant per hill at seedling stage. All the normal agronomic practices were followed as usual in the ordinary cotton field.

The data were scored on eight guarded plants from each row in each replication for the six yield and three fiber quality traits. Boll weight (BW) in grams as the average weight of five opining bolls/plant, seed cotton yield/plant (SCY/P), lint yield/plant (LY/P), lint percentage $(\mathrm{L} \%)$, seed index $(\mathrm{SI})$ and lint index (LI) in grams. Three fiber quality traits were estimated; fiber length $(\mathrm{FL})$ in $\mathrm{mm}$, fiber strength (FS) as Presley index and micronaire value (Mic) were estimated at Cotton Technology Laboratory, Cotton Research Institute, Agricultural Research Center, Giza, Egypt. 


\section{Statistical analysis}

Triple test cross analysis was used as the method proposed by Jinks and Perkins, 1970 to detect epistasis (i) and to test and estimate both additive (D) and dominance $(\mathrm{H})$ components of genetic variance based on general formula:-

$L_{i j k}=\mu+G_{i j}+R_{k}+E_{i j k}$

Where,

$L_{i j k}=$ Phenotypic value of cross between tester $\mathbf{i}$ and line $\mathbf{j}$ in $\mathbf{k}$ replication.

$\mu=$ Overall mean of all single and three way crosses.

$\mathrm{G}_{\mathrm{ij}}=$ Genotypic value of cross between tester $\mathrm{i}$ and line $\mathbf{j}$.

$\mathbf{R}_{k}=$ Effect of $k^{\text {th }}$ replication.

$E_{i j k}=$ Error.

\section{Test of epistasis:-}

For detection of epistasis the contrast $\left(L_{1 i}+L_{2 i}-2 L_{3 i}\right)$ was computed (where $i=$ 1 to 25) from the three replicates. The epistasis sum of squares for 25 degrees of freedom was partitioned into two items 'i' type of epistasis (additive $x$ additive interaction) with 1 degrees of freedom and the other item with 24 degrees of freedom testing for ' $\mathrm{j}$ ' and ' 1 ' types of epistasis (additive $x$ dominance and dominance $x$ dominance interactions, respectively).

Detection and estimation of additive (D), dominance $(\mathrm{H})$ and direction of dominance:

The mean squares due to sums $\left(\mathrm{L}_{1 \mathrm{i}}+\right.$ $\left.L_{2 i}\right)$ and differences $\left(L_{1 i}-L_{2 i}\right)$ for 24 degrees of freedom were used to detect both additive (D) and dominance $(H)$ gene effects. The estimation of $D$ and $H$ were obtained according to Jinks and Perkins, 1970. The direction of dominance $(F)$ was obtained from covariance of sums $\left(\mathrm{L}_{1 \mathrm{i}}+\right.$ $\left.L_{2 i}\right)$ / differences $\left(L_{1 i}-L_{2 i}\right)$ which equal 1/8. Correlation coefficient of sums / differences was used to test the significance of $F$ value (Jinks et al., 1969). The obtained 25 values for each $\left(L_{1 i}+L_{2 i}\right.$
- $\left.L_{3 i}\right),\left(L_{1 i}+L_{2 i}\right)$ and $\left(L_{1 i}-L_{2 i}\right)$ comparisons for every trait were used to compute epistasis, additive and dominance genetic correlations, respectively (Jinks and Perkins, 1970). Also, degree of dominance was calculated as $(H / D)^{1 / 2}$.

Predicting the properties of recombinant lines:

The proportion of superior inbreds falling outside parental range corresponding to the probability level computed from the equation $d / \sqrt{ } D$. whilst, the range of inbreds is given by $\mathrm{m}$ $\pm 2 \sqrt{ }$. Where $d=L_{1}-L_{2}$ and $m=L_{3}$ (Jinks and Ponni, 1976). The proportion of recombinant lines corresponding to the probability level was obtained using Fisher and Yates, 1963 tables.

\section{RESULTS AND DISCUSSIONS}

\section{Analysis of variance}

The analysis of variance of the triple test cross families Giza $95 \times$ Australy, for all traits studied are presented in Table (1). The results showed that between $L_{1}$, $L_{2}$ and $L_{3}$ (TTC) were highly significant for all traits studied, while Between $L_{1}$ and $L_{2}$ Families were found to be significant for boll weight, lint percentage, lint index, fiber length and micronaire value, indicating the presence of high segregations in $F_{2}$. These results might reflect that the parents ( $F_{2}$ Plants) involved in the backcrosses were diverse and that diversity could be transmitted to their progenies.

\section{Mean performance of $L_{1}, L_{2}$ and $\mathrm{L}_{3}$ TTC families:}

The average performance of $L_{1}, L_{2}$ and $\mathrm{L}_{3}$ TTC families for all traits studied are presented in Table (2). The data showed that the means of the backcrosses $L_{1 i}, L_{2 i}$ and $L_{3 i}$ families exhibited significant 
differences for most studied traits. The backcrosses to Australy $\left(L_{2}\right)$ give higher mean values than backcrosses to Giza 95 $\left(L_{1}\right)$ for all yield traits studied except lint percentage, fiber length and fiber strength while backcrosses to Giza 95 $\left(L_{1}\right)$ showed the best mean values of backcrosses than Australy $\left(L_{2}\right)$ for all fiber quality traits except for micronaire value. On the other hand, the backcrosses to $F_{1}\left(L_{3}\right)$ showed higher mean values than backcross to Giza 95 $\left(L_{1}\right)$ or Australy $\left(L_{2}\right)$ for all traits studied except for fiber length. These results indicated that the backcross to Australy $\left(L_{2}\right)$ appeared to improve most yield traits than of backcross to Giza $95\left(L_{1}\right)$. Such results might confirm the high yielding traits of this genotype Australy $\left(\mathrm{L}_{2}\right)$ which might be useful for improving yield traits in any breeding programs.

Table (1): Analysis of variance of triple test cross families for all traits studied in the cotton cross Giza 95 x Australy.

\begin{tabular}{|c|c|c|c|c|c|c|c|c|c|c|}
\hline sov & d.f & BW & SCY/P & LY/P & L\% & SI & LI & FL & Mic & FS \\
\hline Between $L_{1}, L_{2}, L_{3}$ & 74 & $0.10^{\star}$ & $1438.68^{\star \star}$ & $258.54^{\star \star}$ & $5.23^{\star \star}$ & $0.78^{\star \star}$ & $0.42^{\star \star}$ & $2.64^{\star \star}$ & $0.04^{\star \star}$ & $0.17^{\star}$ \\
\hline Between $L_{1}$ & 24 & 0.03 & 130.33 & 22.55 & $4.39^{\star}$ & $1.00^{\star *}$ & 0.35 & $3.09^{* \star}$ & $0.06^{\star \star}$ & 0.11 \\
\hline Between $L_{2}$ & 24 & $0.19^{\star \star}$ & 133.18 & 25.64 & $4.37^{\star}$ & $0.63^{\star}$ & $0.40^{\star}$ & $2.12^{\star \star}$ & $0.03^{\star \star}$ & 0.11 \\
\hline Between $L_{3}$ & 24 & 0.03 & $797.60^{\star \star}$ & $137.96^{\star \star}$ & $6.15^{\star \star}$ & $0.55^{\star}$ & 0.20 & $2.33^{\star \star}$ & $0.03^{\star \star}$ & $0.29^{\star *}$ \\
\hline Residual & 2 & 0.86 & 40497.79 & 7331.98 & 14.55 & 2.75 & 4.00 & 7.18 & 0.21 & 0.17 \\
\hline Within $L_{1}, L_{2}, L_{3}$ & 216 & 0.08 & 500.16 & 88.83 & 3.21 & 037 & 0.29 & 1.11 & 0.02 & 0.14 \\
\hline $\begin{array}{l}\text { Between } L_{1}, L_{2} \\
\text { Families }\end{array}$ & 49 & $0.11^{\star \star}$ & 129.07 & 23.60 & $4.30^{\star}$ & 0.32 & $0.80^{\star \star}$ & $2.55^{\star \star}$ & $0.04^{\star \star}$ & 0.11 \\
\hline $\begin{array}{l}\text { Within } L_{1}, L_{2} \\
\text { Families }\end{array}$ & 144 & 0.01 & 39.12 & 6.92 & 0.54 & 0.02 & 0.06 & 0.06 & 0.004 & 0.01 \\
\hline
\end{tabular}

$L_{1}=$ backcross to Giza $95 \quad L_{2}=$ backcross to Australy $L_{3}=$ backcross to $F_{1}$

Table (2): Mean values of Triple test cross families for the traits studied among cotton cross Giza 95 x Australy.

\begin{tabular}{|l|c|c|c|c|c|c|c|c|c|}
\hline $\begin{array}{c}\text { TTC } \\
\text { families }\end{array}$ & BW g & SCY/P g & LY/P g & L\% & SI g & LI g & FL mm & Mic & FS \\
\hline $\mathrm{L}_{1}$ & $3.26 \pm 0.02$ & $123.61 \pm 1.32$ & $50.48 \pm 0.55$ & $40.41 \pm 0.24$ & $9.67 \pm 0.12$ & $6.37 \pm 0.07$ & $31.06 \pm 0.20$ & $4.38 \pm 0.03$ & $10.26 \pm 0.04$ \\
\hline $\mathrm{L}_{2}$ & $3.33 \pm 0.05$ & $127.38 \pm 1.33$ & $52.02 \pm 0.59$ & $39.93 \pm 0.24$ & $9.86 \pm 0.09$ & $6.60 \pm 0.07$ & $30.62 \pm 0.17$ & $4.44 \pm 0.02$ & $10.23 \pm 0.04$ \\
\hline $\mathrm{L}_{3}$ & $3.47 \pm 0.02$ & $165.61 \pm 3.26$ & $68.32 \pm 1.36$ & $40.62 \pm 0.29$ & $10.05 \pm 0.09$ & $6.83 \pm 0.05$ & $30.46 \pm 0.18$ & $4.49 \pm 0.02$ & $10.32 \pm 0.06$ \\
\hline $\begin{array}{l}\text { LSD at } \\
0.05\end{array}$ & 0.14 & 10.01 & 4.11 & 0.58 & 0.25 & 0.864 & 0.385 & 0.10 & 0.12 \\
\hline
\end{tabular}

$L_{1}=$ backcross to Giza $95 L_{2}=$ backcross to Australy $L_{3}=$ backcross to $F_{1}$ 


\section{Epistasis deviations}

Data given in Table (3) showed the individual epistasis deviations of each $F_{2}$ male for traits studied in the cotton cross (Giza $95 \times$ Australy). Data revealed differences among the individual epistasis deviations in magnitude and sign for all studied yield traits. The magnitudes for epistasis deviations were generally differ between the cotton cross and among 25 males. Some traits showed negative or positive epistasis deviations. Generally, Positive epistasis deviations might indicate the greater observed values of the parental test cross; contribution of the parents was greater than $F_{1}$. While negative individual epistasis deviations could be reflect the greater means of $F_{1}$ test cross compared with $\mathbf{P}_{1}, \mathbf{P}_{2}$ test crosses, where contributions of $F_{1}$ test cross were greater than parental testers.

Table (3): Individual epistasis deviations of each $F_{2}$ male for all the traits studied in the cotton cross Giza 95 × Australy.

\begin{tabular}{|c|c|c|c|c|c|c|c|c|c|}
\hline Traits & BW & SCY/P & LY/P & L\% & SI & LI & FL & Mic & FS \\
TTC & $\mathrm{g}$ & $\mathrm{g}$ & & & & & & \\
\hline L1 & -2.10 & -202.40 & -79.74 & 2.80 & -2.60 & 0.23 & -1.50 & -0.50 & -0.60 \\
\hline L2 & -2.10 & -238.90 & -111.86 & -6.13 & -2.60 & -1.56 & 3.00 & -0.20 & -0.60 \\
\hline L3 & -0.90 & -274.00 & -116.40 & -0.58 & -0.30 & 0.14 & 2.50 & -0.50 & 0.00 \\
\hline L4 & -0.10 & -112.60 & -55.01 & -5.61 & -1.80 & -3.84 & -1.50 & -0.10 & -0.20 \\
\hline L5 & -0.80 & -255.90 & -107.40 & -1.99 & -2.70 & -2.85 & -1.00 & 0.00 & -0.20 \\
\hline L6 & -0.10 & -275.70 & -121.37 & -5.10 & -2.20 & -3.08 & 0.50 & 0.10 & 0.80 \\
\hline L7 & -1.30 & -261.30 & -114.45 & -5.14 & -2.40 & -5.31 & 3.00 & -1.20 & 2.20 \\
\hline L8 & -0.60 & -177.10 & -69.72 & 2.58 & -0.40 & -2.56 & 3.00 & -1.10 & 0.20 \\
\hline L9 & -0.90 & -323.40 & -129.41 & -3.92 & 2.90 & -0.32 & -5.50 & 0.10 & -2.50 \\
\hline L10 & -1.00 & -241.70 & -91.52 & -0.15 & 3.20 & -2.65 & 0.00 & 0.70 & -2.20 \\
\hline L11 & -1.60 & -436.50 & -185.16 & 10.87 & -0.10 & -1.36 & 1.50 & 0.00 & -3.00 \\
\hline L12 & -0.80 & -212.00 & -85.17 & 24.26 & -2.40 & -2.01 & 0.50 & 0.40 & -1.10 \\
\hline L13 & -0.50 & -205.00 & -91.98 & 15.34 & -0.90 & 2.52 & 1.00 & -0.60 & 0.00 \\
\hline L14 & -1.20 & -229.20 & -93.20 & 15.21 & -1.00 & -3.40 & 1.50 & -0.70 & 0.00 \\
\hline L15 & -0.60 & -290.20 & -139.91 & 3.17 & 0.50 & -5.03 & 2.00 & -0.10 & 1.70 \\
\hline L16 & -0.10 & -117.50 & -51.61 & -2.60 & -1.30 & -3.43 & -2.00 & 0.30 & -0.40 \\
\hline L17 & -0.80 & -222.50 & -91.48 & -6.53 & -2.80 & -1.51 & 6.00 & -0.40 & 0.10 \\
\hline L18 & -0.60 & 1.20 & -3.14 & -8.55 & -4.40 & -3.00 & 0.00 & -0.90 & 0.80 \\
\hline L19 & -1.60 & -187.10 & -83.15 & -11.21 & -2.20 & -0.33 & 0.50 & 0.40 & 0.40 \\
\hline L20 & -1.10 & -356.10 & -150.55 & -6.62 & -5.00 & -3.13 & -3.50 & -2.60 & 0.60 \\
\hline L21 & 0.50 & -99.80 & -42.40 & -9.70 & -3.90 & -2.18 & 2.00 & -1.30 & -0.60 \\
\hline L22 & -0.30 & -249.90 & -102.94 & -14.25 & -3.40 & 0.50 & 1.50 & 0.50 & -1.50 \\
\hline L23 & -4.00 & -303.70 & -142.66 & -27.06 & -3.90 & -5.86 & -4.50 & -0.70 & -2.80 \\
\hline L24 & -1.80 & -483.30 & -192.90 & -17.80 & -0.50 & 0.50 & 1.50 & -1.80 & -2.40 \\
\hline L25 & -1.90 & -262.80 & -107.90 & -12.98 & -3.10 & -2.59 & 0.00 & -0.80 & -0.60 \\
\hline & & & & & & & & & \\
\hline
\end{tabular}




\section{Tests for epistasis}

The existence of non-allelic interactions for economic traits might have important inferences in plant breeding. The (i) type epistasis represents fixable while $(j+l)$ types show non-fixable portions of genetic variations. Genetic analyses of the data revealed epistasis affected all the traits studied (Table 4). The mean square for the deviations overall epistasis $\left(L_{1 i}+L_{2 i}\right.$ $2 \mathrm{~L}_{3 i}$ ) revealed the presence of significant epistasis for boll weight, seed cotton yield/plant, lint yield/plant and lint percentage. Further partitioning of total epistasis into (i) epistatic type (additive $x$ additive), ( $j+l)$ epistatic types (additive $x$ dominance) and (dominance $x$ dominance) interactions showed that mean squares estimates due to additive $x$ additive (i) type were found to be highly significant for all the traits studied except fiber strength. The presence of $(j+l)$ epistatic types appeared to be highly significant in the inheritance of lint percentage. The epistatic type (i), was detected to be much larger in magnitudes than the other epistatic type $(j+l)$ interactions for all traits studied, indicating that fixable components of epistasis were more important than nonfixable one in the inheritance of these traits. Since, epistasis plays an important role in governing most of the traits under study and result in biased estimates for the genetic variance. Thus ignoring such effect lead to loss information about epistasis also the estimates of additive and dominance components would be biased. Thus, the breeder should take epistasis into account in producing genetic models for studying quantitative traits (El-Mansy et al., 2012 and 2020).

In self-fertilized crops like cotton, the fixable component of epistasis could be easily exploited. The presence of epistasis could have important implications in a breeding program. Standard hybridization and selection procedures could take advantage of epistasis if it is additive $x$ additive epistatic type as in most traits studied. A great importance of epistasis was also recorded in cotton by Hussain et al., (2008), Sohu et al., (2010), El-Lawendey et al., (2010), Saleh (2013) and Jayade et al., (2014).

5. Detection and estimation of additive and dominance genetic variance components

Analysis of variance for sums, additive $\left(L_{1 i}+L_{2 i}\right)$ and difference, dominance $\left(L_{1 i}-L_{2 i}\right)$ is presented in (Table 5). The mean square due to sums and differences were found to be highly significant for all the traits studied, indicating the presence of both additive and dominance genetic variance for these traits. These results were in line with those of many researchers Hendawy et al., (2009), El-Mansy et al., (2010 and 2012), Kannan et al., (2013), Ali et al., (2016) and Mahros, (2016).

Table 4: Analysis of variance for testing the presence of epistasis in a triple test cross for all traits studied in the cotton cross Giza $95 \times$ Australy.

\begin{tabular}{|l|c|c|c|c|c|c|c|c|c|c|}
\hline \multicolumn{1}{|c|}{ S.O.V } & d.f & BW & SCY/P & LY/P & L\% & SI & LI & FL & Mic & FS \\
\hline $\begin{array}{l}\text { i type of } \\
\text { epistasis }\end{array}$ & 1 & $9.22^{\star \star}$ & $482788.03^{\star \star}$ & $87451.25^{\star \star}$ & $68.52^{\star}$ & $25.00^{\star \star}$ & $36.18^{\star \star}$ & $42.87^{\star \star}$ & $1.61^{\star \star}$ & 1.89 \\
\hline $\begin{array}{l}\text { (j + I) types } \\
\text { of epistasis }\end{array}$ & 24 & 0.27 & 3447.74 & 596.10 & $40.84^{\star \star}$ & 1.35 & 1.34 & 4.79 & 0.18 & 0.59 \\
\hline $\begin{array}{l}\text { Overall } \\
\text { Epistasis }\end{array}$ & 25 & $0.63^{\star}$ & $22621.35^{\star \star}$ & $4070.31^{\star \star}$ & $41.94^{\star \star}$ & 2.29 & 2.73 & 6.31 & 0.25 & 0.65 \\
\hline $\begin{array}{l}\text { Within } \\
\text { Families } L_{1}, \\
\mathrm{~L}_{2}, \mathrm{~L}_{3}\end{array}$ & 216 & 0.08 & 500.16 & 88.83 & 3.21 & 0.37 & 0.29 & 1.11 & 0.02 & 0.14 \\
\hline
\end{tabular}


Table 5: Mean squares for sums (additive) and differences (dominance) test for triple test cross families for the studied traits of the cotton cross Giza $95 \times$ Australy.

\begin{tabular}{|l|c|c|c|c|c|c|c|c|c|c|}
\hline \multicolumn{1}{|c|}{ S.O.V } & d.f & BW & SCY/P & LY/P & L\% & SI & LI & FL & Mic & FS \\
\hline $\begin{array}{l}\text { Between } \\
\text { sums }\end{array}$ & 24 & $0.24^{\star \star}$ & $268.04^{\star \star}$ & $45.85^{\star \star}$ & $11.95^{\star \star}$ & $1.39^{\star \star}$ & $0.64^{\star \star}$ & $8.960^{\star \star}$ & $0.11^{\star \star}$ & $0.41^{\star \star}$ \\
\hline Within sums & 216 & 0.05 & 56.52 & 11.53 & 1.49 & 0.16 & 0.12 & 0.50 & 0.01 & 0.13 \\
\hline $\begin{array}{l}\text { Between } \\
\text { differences }\end{array}$ & 24 & $0.19^{\star \star}$ & $258.98^{\star \star}$ & $50.53^{\star \star}$ & $6.20^{\star}$ & $1.86^{\star \star}$ & $0.864^{\star \star}$ & $1.46^{\star \star}$ & $0.07^{\star \star}$ & $0.02^{\star \star}$ \\
\hline $\begin{array}{l}\text { Within } \\
\text { differences }\end{array}$ & 144 & 0.07 & 70.37 & 14.02 & 3.61 & 0.25 & 0.248 & 0.64 & 0.01 & 0.01 \\
\hline
\end{tabular}

The TTC analyses further showed that although both additive (D) and dominance $(\mathrm{H})$ genetic components of variation appeared to predominantly affect all traits (Table 5). Additive values were greater than dominance genetic variance for all studied traits except for lint yield/plant, seed index and lint index. The degree of dominance ( $\sqrt{ } \mathrm{H} / \mathrm{D}$ ) was less than unity suggesting the role of partial or incomplete dominance for all the traits studied except for lint yield/plant, seed index and lint index which showed overdominance (greater than unity). Consequently, it concluded that selection procedures in early generations based on accumulation of additive effects would be successful in improving all these traits. Similar results were previously obtained by Saleh 2013, Dawwam et al., 2016 and El-Mansy et al., 2020.

Further, the correlation coefficient between the sums $\left(L_{1 i}+L_{2 i}\right)$ and difference $\left(L_{1 i}-L_{2 i}\right)$ were found to be negative and insignificant for all traits except boll weight (Table 6). However, seed index, fiber length and micronaire value were positive and non-significant. These results indicated that the genes with positive and negative dominant alleles were dispersed between testers and did not show any proof of directional dominance for these traits. The covariance of sums and differences (F) value was insignificant and negative for most traits studied, reflecting ambidirectional dominance. Hendawy et al., (2009) observed that the correlation coefficient for number of fruiting branches per plant was found to be negative and highly significant then increasing type of genes are dominant. El-Lawendey et al., (2010) indicated that the correlation coefficient of sums and differences was non- significant for all characters, the F-values were positive and negative, revealing that dominant genes were umbidirectional among parents. Significant positive additive correlation between lint yield/plant and each of lint index and seed index were detected.

\section{Genetic correlation:}

The kind of relationships, which may occur among traits, is an important tool for selection in breeding programs. Partitioning the total genetic variation to its components; additive $\left(r_{\mathrm{D}}\right)$, dominance $\left(r_{H}\right)$ and epistasis $\left(r_{i}\right)$ and genotypic correlation is illustrated in Table 7 . The results obtained provide evidence for positive and significant correlation between additive gene effects controlling between boll weight and seed cotton yield/plant and lint yield/plant. Also, between seed cotton yield/plant and lint yield/plant and seed index and lint index. While, negative and significant genotypic correlation recorded between lint $\%$ and seed index. 
Table (6): Estimates of additive (D), dominance (H) components, degree of dominance $(H / D)^{0.5}$ and covariance between sums and differences $(F)$ for all traits studied in the cotton cross Giza $95 \times$ Australy.

\begin{tabular}{|c|c|c|c|c|c|c|c|c|c|}
\hline Items & $\begin{array}{c}\text { BW } \\
\text { g }\end{array}$ & $\begin{array}{c}S C Y / P \\
g\end{array}$ & $\begin{array}{c}\mathrm{LY} / \mathrm{P} \\
\mathrm{g}\end{array}$ & L\% & $\begin{array}{l}\text { SI } \\
\text { g }\end{array}$ & $\begin{array}{l}\text { LI } \\
\text { g }\end{array}$ & $\begin{array}{c}\mathrm{FL} \\
\mathrm{mm}\end{array}$ & Mic & FS \\
\hline D & 0.26 & 282.03 & 45.76 & 13.94 & 1.63 & 0.70 & 11.28 & 0.12 & 0.38 \\
\hline H & 0.16 & 251.48 & 48.68 & 3.45 & 2.15 & 0.82 & 1.10 & 0.08 & 0.02 \\
\hline$(H / D)^{0.5}$ & 0.79 & 0.94 & 1.03 & 0.50 & 1.15 & 1.08 & 0.31 & 0.79 & 0.21 \\
\hline$F$ & -0.46 & -8.22 & -8.88 & -0.82 & 1.07 & -0.04 & 2.79 & 0.06 & -0.01 \\
\hline $\begin{array}{c}r \\
\text { (sums/differences) }\end{array}$ & $-0.75^{\star \star}$ & -0.01 & -0.06 & -0.03 & 0.23 & -0.06 & 0.27 & 0.26 & -0.05 \\
\hline
\end{tabular}

${ }^{*},{ }^{\star \star}$ Significant at 0.05 and 0.01 levels, respectively.

Table 7: Genotypic correlation between epistasis (i), additive (D) and dominance (H) for all traits studied in the cotton cross Giza $95 \times$ Australy.

\begin{tabular}{|c|c|c|c|c|c|c|c|c|c|}
\hline Traits & & $\begin{array}{c}\text { SCY/P } \\
g \\
\end{array}$ & $\begin{array}{c}\mathrm{LY} / \mathrm{P} \\
\mathbf{g}\end{array}$ & L\% & $\begin{array}{l}\text { SI } \\
\text { g }\end{array}$ & $\begin{array}{l}\text { LI } \\
\mathbf{G}\end{array}$ & $\begin{array}{c}\mathrm{FL} \\
\mathrm{mm}\end{array}$ & Mic & FS \\
\hline \multirow{3}{*}{$\begin{array}{c}\text { BW } \\
\text { g }\end{array}$} & $r_{i}$ & $0.44^{\star}$ & $0.47^{\star}$ & 0.16 & 0.20 & 0.28 & 0.25 & 0.15 & 0.39 \\
\hline & $r_{D}$ & $0.41^{*}$ & $0.40^{*}$ & 0.01 & 0.33 & 0.38 & 0.14 & 0.33 & -0.15 \\
\hline & $\mathbf{r}_{\mathbf{H}}$ & 0.08 & 0.08 & 0.00 & -0.21 & -0.18 & -0.19 & 0.09 & -0.07 \\
\hline \multirow{3}{*}{$\begin{array}{c}\text { SCY/P } \\
g\end{array}$} & $r_{i}$ & & $0.98^{\star \star}$ & 0.00 & -0.01 & 0.01 & 0.07 & 0.19 & $0.42^{\star}$ \\
\hline & $r_{D}$ & & $0.95^{\star \star}$ & -0.12 & 0.06 & -0.02 & 0.19 & -0.04 & 0.22 \\
\hline & $\mathbf{r}_{\mathrm{H}}$ & & $0.95^{\star *}$ & 0.11 & -0.12 & 0.01 & 0.17 & 0.36 & -0.38 \\
\hline \multirow{3}{*}{$\begin{array}{c}\mathrm{LY} / \mathrm{P} \\
\mathbf{g}\end{array}$} & $r_{i}$ & & & 0.16 & -0.03 & 0.11 & 0.07 & 0.18 & 0.36 \\
\hline & $r_{D}$ & & & 0.18 & -0.09 & 0.04 & 0.28 & -0.02 & 0.29 \\
\hline & $\mathbf{r}_{\mathrm{H}}$ & & & $0.39^{\star}$ & -0.23 & 0.15 & 0.19 & $0.43^{\star}$ & -0.24 \\
\hline \multirow{3}{*}{ L\% } & $r_{i}$ & & & & -0.19 & $0.60^{\star \star}$ & 0.06 & -0.04 & -0.29 \\
\hline & $r_{D}$ & & & & $-0.49^{*}$ & 0.22 & 0.28 & 0.07 & 0.24 \\
\hline & $\mathbf{r}_{\mathrm{H}}$ & & & & $-0.43^{\star}$ & $0.48^{*}$ & 0.11 & 0.36 & 0.38 \\
\hline \multirow{3}{*}{$\begin{array}{l}\text { SI } \\
\text { g }\end{array}$} & $r_{i}$ & & & & & $0.67^{\star \star}$ & 0.02 & 0.12 & 0.27 \\
\hline & $r_{D}$ & & & & & $0.73^{\star \star}$ & -0.23 & 0.08 & -0.17 \\
\hline & $\mathbf{r}_{\mathbf{H}}$ & & & & & $0.58^{\star *}$ & 0.12 & -0.09 & 0.15 \\
\hline \multirow{3}{*}{$\begin{array}{l}\text { LI } \\
\text { g }\end{array}$} & $r_{i}$ & & & & & & 0.07 & 0.06 & 0.01 \\
\hline & $r_{D}$ & & & & & & -0.04 & 0.13 & 0.00 \\
\hline & $r_{H}$ & & & & & & 0.21 & 0.23 & $0.48^{x}$ \\
\hline \multirow{3}{*}{$\begin{array}{c}\mathrm{FL} \\
\mathrm{mm}\end{array}$} & $r_{i}$ & & & & & & & -0.01 & 0.36 \\
\hline & $r_{D}$ & & & & & & & 0.23 & 0.15 \\
\hline & $\mathbf{r}_{\mathrm{H}}$ & & & & & & & -0.19 & 0.12 \\
\hline \multirow{3}{*}{ Mic } & $r_{i}$ & & & & & & & & -0.22 \\
\hline & $r_{D}$ & & & & & & & & 0.04 \\
\hline & $\mathbf{r}_{\mathbf{H}}$ & & & & & & & & -0.15 \\
\hline
\end{tabular}


Concerning the dominance genotypic correlations, the results showed positive and significant correlation between seed cotton yield / plant and lint yield/plant, lint yield/plant and lint $\%$, lint $\%$ and lint index, seed index and lint index and lint index and fiber strength. On the other hand, negative and significant genotypic correlation was between lint $\%$ and seed index (Table 7). Regarding epistasis genotypic correlation the results indicated positive and significant correlation between boll weight and seed cotton yield / plant and lint yield/plant, seed cotton yield/plant and lint yield/plant, lint $\%$ and lint index and seed index and lint index.

The results of genotypic correlation showed that most of the yield traits were associated with each other and confirmed that selection for any one will improve the other traits. So, the cotton breeder can increase yield productivity by using indirect selection for yield components. Makhdoom et al., 2010 and El-Mansy et al., 2020 reported that boll weight is the independent key for yield components and played a prime role in managing seed cotton yield. These results are in agreement with Farooq et al., 2014 and El-Mansy 2015.

\section{Prediction of superior recombinants:}

Table 8: Predications range of inbreed lines and the proportion of inbreeds expected to fall outside their parental range for all the studied traits

\begin{tabular}{|c|c|c|c|c|c|c|}
\hline \multirow[b]{2}{*}{ Traits } & \multicolumn{3}{|c|}{ Parameters } & \multirow{2}{*}{$\begin{array}{l}\text { Range of } \\
\text { inbreeds } \\
m \pm 2 \sqrt{ }\end{array}$} & \multirow{2}{*}{$\begin{array}{l}\text { Probability } \\
\text { [d] } / \sqrt{ } \text { D }\end{array}$} & \multirow{2}{*}{$\begin{array}{l}\text { Proportion of inbreeds } \\
\text { falling outside parental } \\
\text { range \% }\end{array}$} \\
\hline & [m] & [d] & (D) & & & \\
\hline BW & 3.087 & 0.110 & 0.257 & 2.073-4.101 & 0.217 & 41.683 \\
\hline SCY & 84.397 & 7.153 & 282.028 & $50.809-117.984$ & 0.426 & 33.724 \\
\hline LY & 32.853 & 2.809 & 45.758 & $19.324-46.382$ & 0.415 & 34.090 \\
\hline$L \%$ & 38.973 & -0.017 & 13.944 & $31.504-46.441$ & -0.005 & 48.006 \\
\hline LI & 5.913 & -0.017 & 1.634 & $4.240-7.587$ & 0.253 & 40.129 \\
\hline SI & 9.273 & 0.320 & 0.700 & $6.717-11.830$ & 0.250 & 40.129 \\
\hline FL & 30.465 & 0.065 & 11.282 & $23.747-37.183$ & 0.019 & 49.601 \\
\hline MIC & 4.593 & 0.067 & 0.124 & $3.889-5.297$ & 0.190 & 42.465 \\
\hline FS & 9.932 & -0.063 & 0.377 & $8.704-11.160$ & -0.103 & 46.017 \\
\hline
\end{tabular}


Finally, triple test cross (TTC), was originally proposed by Kearsey and Jinks, 1968 provides not only a direct test for significance of epistatic variance component but also unbiased estimates of additive and dominant components whenever epistasis among polygenes is absent, genetic correlation and Predicting of superior recombinants that could be derived after series of selfing generations. This study could help cotton breeder for rightful decision about the effective breeding method to be applied for improving economic traits in cotton.

\section{REFERENCES}

Abd El-Moghny, A. M. (2016). Genetic analysis and prediction of new recombination in some cotton (G. barbadense L.) crosses. J. Agric. Res. Kafr El-Sheikh Univ. A. Plant Production, 42 (3): 319-335.

Ali, I., A. Shakeel, A. Ali and B. Sadia (2016). Genetic basis of variation for within-boll yield components in cotton. Turk. J. Agric. For., 40: 18-24.

Dawwam, H. A., F. A. Hendawy, M. A. Abd El-Aziz, R. M. Esmail, A. B. Khatab and El-Shymaa, H. Mahros (2016). Using triple test cross technique for partitioning the components of genetic variance and predicting the properties of new recombinant inbred lines in cotton ( $G$. barbadense L.). $10^{\text {th }}$ Inter. Plant Breed. Conf., 5-6 September, Fac. Agric. Menoufia Univ.

El-Lawendey, M. M., Y. M. El-Mansy and M. E. Abd El-Salam (2010). Determination of genetic components through triple test cross in cotton ( $G$. barbadense L.). J. Agric. Res. Kafer EISheikh Univ. 36: 240-257.

EL-Mansy Y. M. (2005). Using genetic components for predicting new recombination in some cotton crosses. Ph.D. Thesis, Fac. of Agric. Mansoura University, Egypt.

El-Mansy, Y. M., W. M. B. Yehia and M. A. El-Dahan (2010). Role of epistasis in the inheritance of traits related to earliness in cotton. Menoufia, J. Agric. Res. 35(2):635-648.

El-Mansy, Y. M., M. M. El-Lawendey and M. A. A. El-Dahan (2012). Genetic variability in growth habit and development of boll and its relation with yield and fiber traits in Egyptian cotton. Egypt. J. Plant Breed. 16(1): 83-97.

El-Mansy, Y. M. (2015). Impact of mating system on genetic variability and correlation coefficients in cotton ( $G$. barbadense L.,). Menoufia J. Agric. Res. 40(1): 119-129.

EL-Mansy, Y. M., A. M. Abdelmoghny, Reham H. A. O. Gibely and A. H. Mabrouk (2020). Relationship between combining ability, genetic components and genetic diversity using triple test cross in cotton. $16^{\text {th }}$ Int. Conf. Crop Sci. Al-Azher Univ. 1314 October.

Farooq, J., M. Anwar, M. Riaz, A. Farooq and F. Ilahi (2014). Correlation and path coefficiency analysis of earliness, fiber quality and yield contributing traits in cotton $G$. hirsutum L. J. Anim. Plant Sci., 24(3): 781-790.

Fisher, R. A. and F. Yates (1963). Statistical Tables for Biological Agricultural and Medical Research. Edinburgh. Oliver and Boyd.

Hendawy, F. A., H. A. Dawwam, R. M. Esmail and El-Shymaa H. Mahros (2009). Triple test cross analysis in some cotton crosses. $6^{\text {th }}$ Int. Plant Breed. Conf. Ismailia, Egypt, 750-763.

Hussain, M., F. M. Azhar and A. A. Khan (2008). Genetic basis of variation in leaf area, petiole length and seed cotton yield in some cotton (Gossypium hirsutum) genotype. Int. J. Agric. and Biology; 10(6): 705-708.

Jayade, V. S., S. R. Patil, P. D. Peshattiwar and and R. D. Deotale (2014). Simplified triple test cross 
analysis for yield, yield contributing and fiber traits in cotton (Gossypium hirsutum L.,). Inter. J. Res. Biosci. Agric. \& Tech., 2 (II): 177-187.

Jinks, I. L. and J. M. Perkins (1970). A general method for the detection of additive, dominance and epistatic components of variation.III. $F_{2}$ and backcross populations. Heredity, 25: 419429.

Jinks, I. L. and H. S. Pooni (1976). Predicting the properties of recombinant inbred lines derived by single seed descent. Heredity 36: 253266.

Kannan, S., R. Ravikesavan and M. Govindaraj (2013). Genetic analysis for quantitative and quality traits in three single crosses of upland cotton. Notulae Scientia Biologicae; 5(4):450453.

Kearsey, M. J. and J. L. Jinks (1968). A general method of detecting additive, dominance and epistatic variation for metrical traits. I. Theory, Heredity, 23: 403-409.

Mahros, H. El-Shymaa (2016). Inheritance of seed cotton yield and its components using triple test cross analysis in some cotton crosses. Ph.D. Fac. Agric. Menoufia Univ.

Makhdoom, K., N. U. Khan, S. Batool, Z.
Bibi, Farhatullah, S. Khan, F. Mohammad, D. Hussain, Raziuddin, M. Sajjad and N. Khan (2010). Genetic aptitude and correlation studies in Gossypium hirsutum L. Pak. J. Bot., 42(3): 2011-2017.

Saleh, M. R. M. Eman (2013). Genetic estimation of yield and yield components in cotton through triple test cross analysis. J. Plant Prod. Mansoura Univ., 4 (2): 229-237.

Sharma, J. R. 1988. Statistical and Biometrical Techniques in Plant Breeding. New Delhi, New Age International.

Sing, P. and S. S. Narayanan (2013). Biometrical Techniques in Quantitative Genetics in Plant Breeding. Kalyani Publ., $5^{\text {th }}$ Ed. New Delhi.

Soliman, Y. A. M., Y. M. El-Mansy and M. A. M. Allam (2008). Triple test cross analysis of some economic characters in cotton G. barbadense. Egypt. J. of Appl. Sci., 23 (4A): 125-137.

Sohu, R. S., M. Dilawari, P. Singh, B. S. Gill and G. S. Chahal (2010). Inheritance studies for earliness, yield and fibre traits using simplified triple test cross in G. hirsutum. Indian J. Genet. Plant Breed. 70(1): 71-75. 
دور التفاعل الغير أليلي في وراثة بعض الصفات الاثتصادية في اقطان الباريادنس

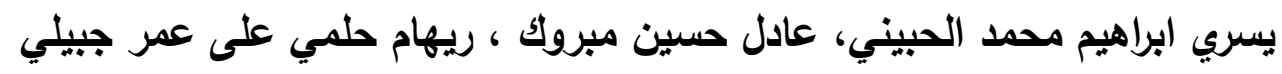

معهر بحوث القطن ، مركز البحوث الزراعية ، الجيزة ، مصر

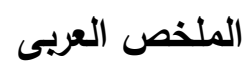

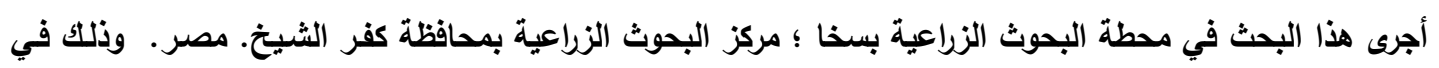

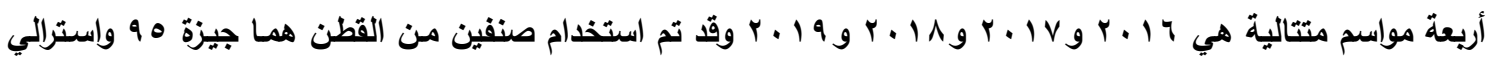

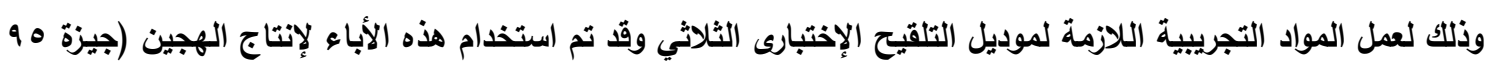

× أسترالي)

وذلك بهـف دراسـة كل من : دور التفوق في وراثة بعض الصفات المحصولية وصفات الجودة للهجين (جيزة ه9 × أسترالي) باستخدام موديل التهجين الإختبارى الثلاثي (Triple test cross) وكنلك تقدير التباين الوراثى المضيف وصفيف

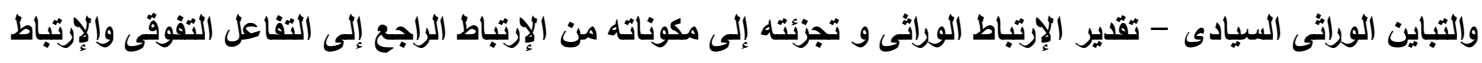

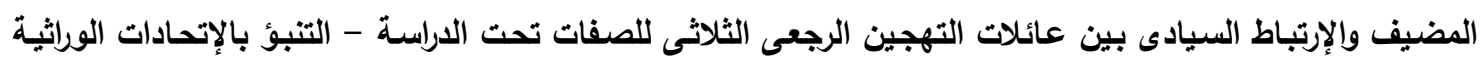
الجديدة والتى تتفوق على حدود الأبوين. وقد تم تحليل البيانات باستخدام طريقة

Kearsey and Jinks (1968), Jinks et al., (1969) and Jinks and Perkins (1970).

ويُمكن تلخيص النتائج المتحصل عليها كما بليف: • كان متوسط مريع الانحرافات من تحليل التباين والتأثيرات الوراثية لجميع الصفات المدروسة عالى المعنوية باستثناء صفتى طول و متانة التيلة .

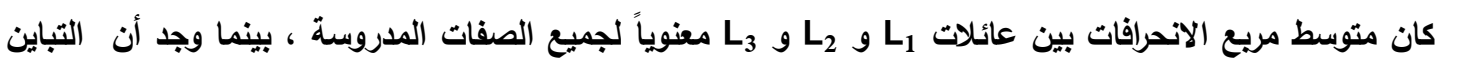

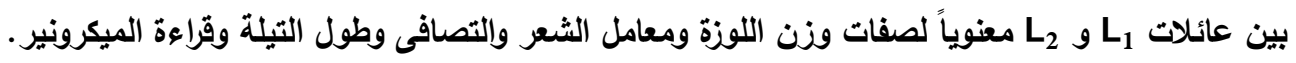

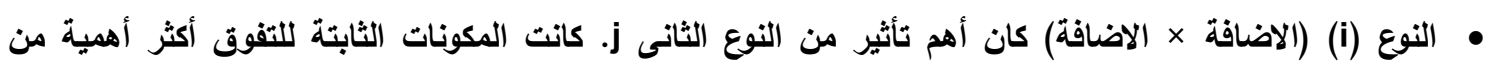

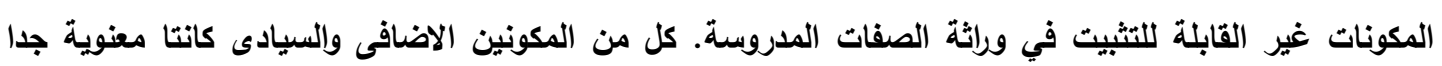
لجميع الصفات المدروسة. كانت درجة السيادة أقل من الواحد مما يعنى وجود سيادة جزئية لجميع الصفات المدروسة باستثناء صفات محصول

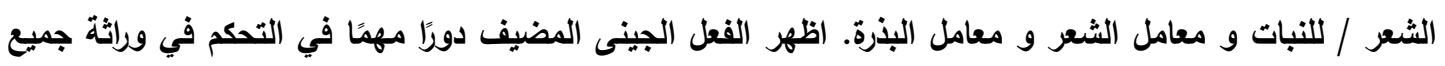

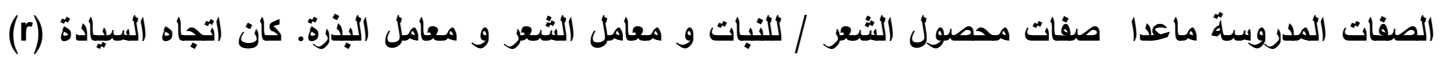

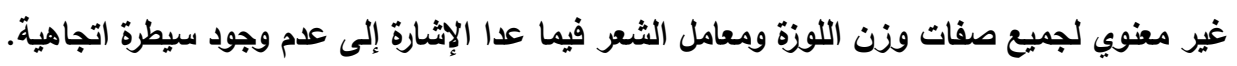
• اظهر الارتباط الوراثى وجود علاقة موجبة ومعنوية بين معظم صفات المحصول ومكوناتة وهذا يتيح للمربى امكانية استخدام الانتخاب الغير مباشر لزيادة المحصول.

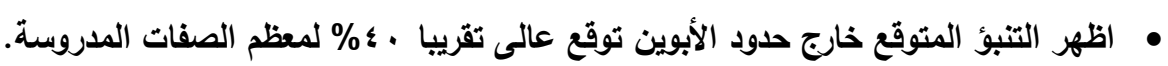

السادة المحكمين

مركز البحوث الزراعية

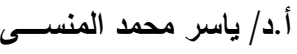

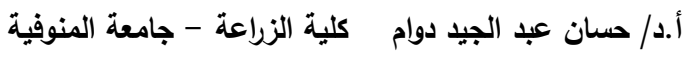


The role of Non-allelic interaction in inheritance of some economic traits in ......... 